\title{
IRF5 wt Allele
}

National Cancer Institute

\section{Source}

National Cancer Institute. IRF5 wt Allele. NCI Thesaurus. Code C124987.

Human IRF5 wild-type allele is located in the vicinity of $7 q 32$ and is approximately $12 \mathrm{~kb}$ in length. This allele, which encodes interferon regulatory factor 5 protein, plays a role in the regulation of interferon and inflammatory cytokine expression. Mutation of the gene is associated with inflammatory bowel disease 14 and susceptibility to systemic lupus erythematosus 10. 